The Collapse of the Concert of Europe 


\section{The Collapse of the Concert of Europe}

\section{International Politics, 1890-1914}

\section{RICHARD LANGHORNE}

Fellow of St John's College, Cambridge

The signal fires of warning

They blaze, but none regard;

And on through night till morning

The world runs ruinward

A E Housman

(More Poems, xLIII)

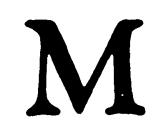


(C) Richard Langhorne 1981

All rights reserved. No part of this publication may be reproduced or transmitted, in any form or by any means, without permission.

First edition 1981

Reprivted 1983

Published by

THE MACMILLAN PRESS LTD

London and Basingstoke

Companies and representatives throughout

the world

ISBN 978-0-333-29213-6 ISBN 978-1-349-86092-0 (eBook)

DOI 10.1007/978-1-349-86092-0 


\section{Contents}

Foreword vii

Map Section ix

Part 1: The Bases of Insecurity

1. The General Context 3

2. Outside Europe: Africa and the Far East 8

3. Inside Europe: Domestic Pressures and the Redistribution of Power in Central Europe 29

4. The Role of Technological Change 56

Part 2: The Response to Insecurity

5. The Grouping of Powers, 1890-1907 69

6. The Road to War, 1907-1914 97

7. The Moment of Collapse, 1914109

List of Principal Dates 122

References 124

Index 131

The illustration on the front of the book shows the signing of the Treaty of Peace between Turkey and the Balkan States at St James's Palace on 30 May 1913, and is reproduced by kind permission of the Illustrated London News Photographic Library. This peace treaty was made possible by the work of a conference of the London Ambassadors of the five great powers, which had met since December 1912 under the chairmanship of Sir Edward Grey, the British Foreign Secretary. This conference was the last example of the Concert of Europe in action. 
For HELEN 


\section{Foreword}

This book is designed to show the working of the principal aspects of international politics, 1890-1914, in a thematic way. It does not seek to give merely a narrative account, nor does it attempt to rely only upon a repetition and summing up of the most modern work specifically upon Germany - though that is a very important theme. It is also necessary to identify and describe other significant factors which were working to destroy the structure of international relations as they had developed since 1815. The development of the Concert of Europe during the nineteenth century had produced the most successful system for regulating international politics that has yet been devised, and in discovering why it collapsed during the period under discussion, substantial clues towards an explanation of the outbreak of war in 1914 emerge.

The themes which are discussed cover the emergence of a nonEuropean sphere of international politics, reaching a crisis point in the Far East at the turn of the century; the effects of a change in the distribution of power occurring in Germany's favour, thus rendering her domestic condition of more than usual significance, as also that of her ally Austria-Hungary; the consequences of the technological and demographic changes of the period, particularly upon communication, weaponry, and the way in which advanced states were coming to be governed. The latter part of the book shows how the general uneasiness and some specific anxieties induced by these developments evoked observable responses from governments, responses which though in some ways were designed to buttress, in fact set in train a gradual collapse of the Concert of Europe. Finally, these developments and responses coincided in their effects and resulted in the failure of states to control the crisis of 1914. This process is described in the last chapter of the book.

I am deeply grateful for the help I have received in writing this book from Professor Maurice Larkin of the University of Edinburgh, Professor F. H. Hinsley, Master of St John's College, Cambridge, Professor 
viii

Foreword

F. S. L. Lyons, Provost of Trinity College, Dublin and Professor Geoffrey Warner of the University of Leicester. I would not have written this book without the encouragement and constant questioning of several generations of history students at the University. of Kent, and although it is too large a number to name each individually, I am grateful to them all.

Cambridge 1980

R. T. B. L. 


\section{Map Section}

\section{List of Maps}

Map 1 Europe, $c 1914$

Map 2 Africa, $c 1880$

Map 3 Africa, 1914

Map 4 The Far East, 1890-1914

Map 5 Cable Map of the World, $c 1905$ 


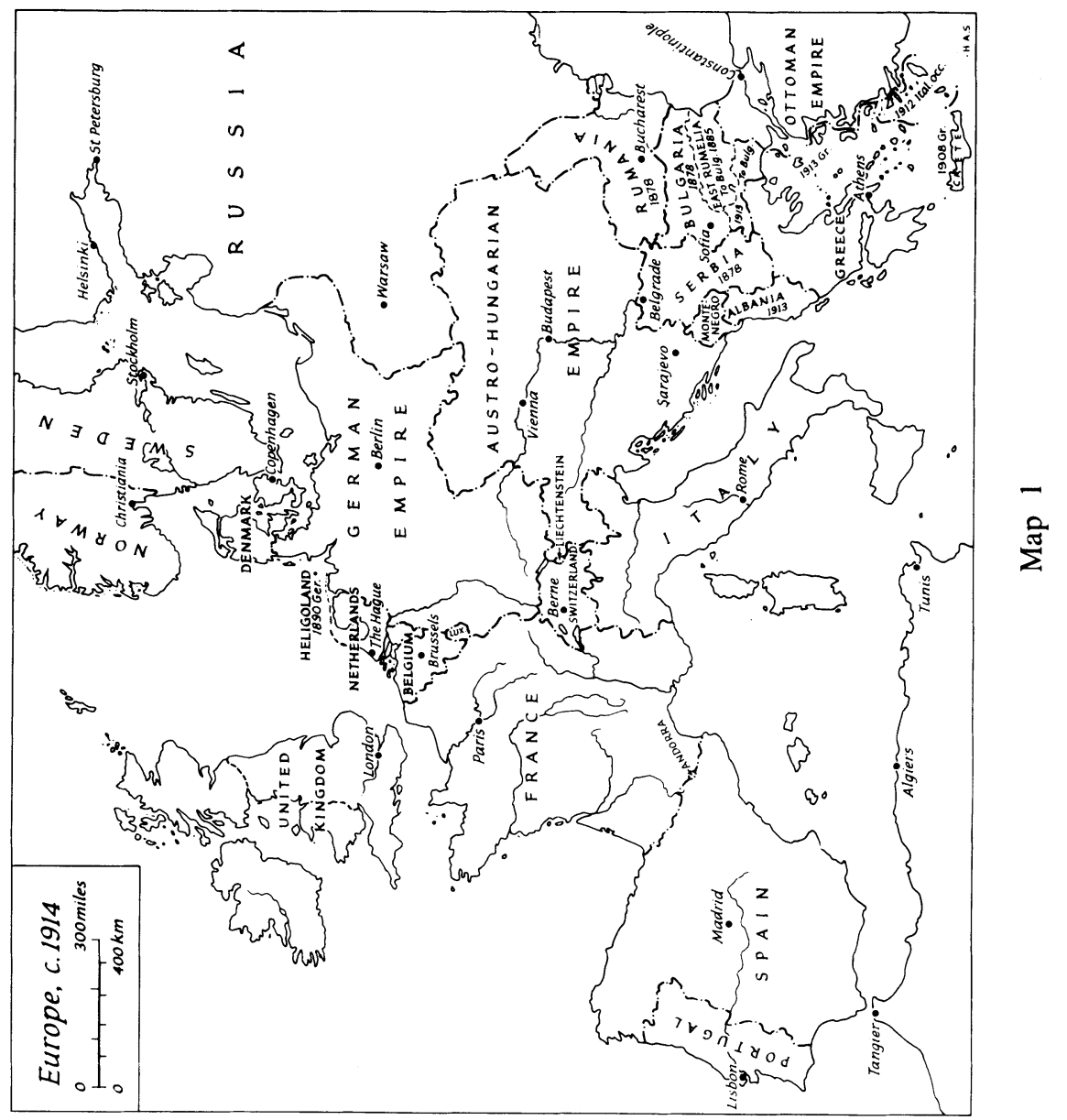




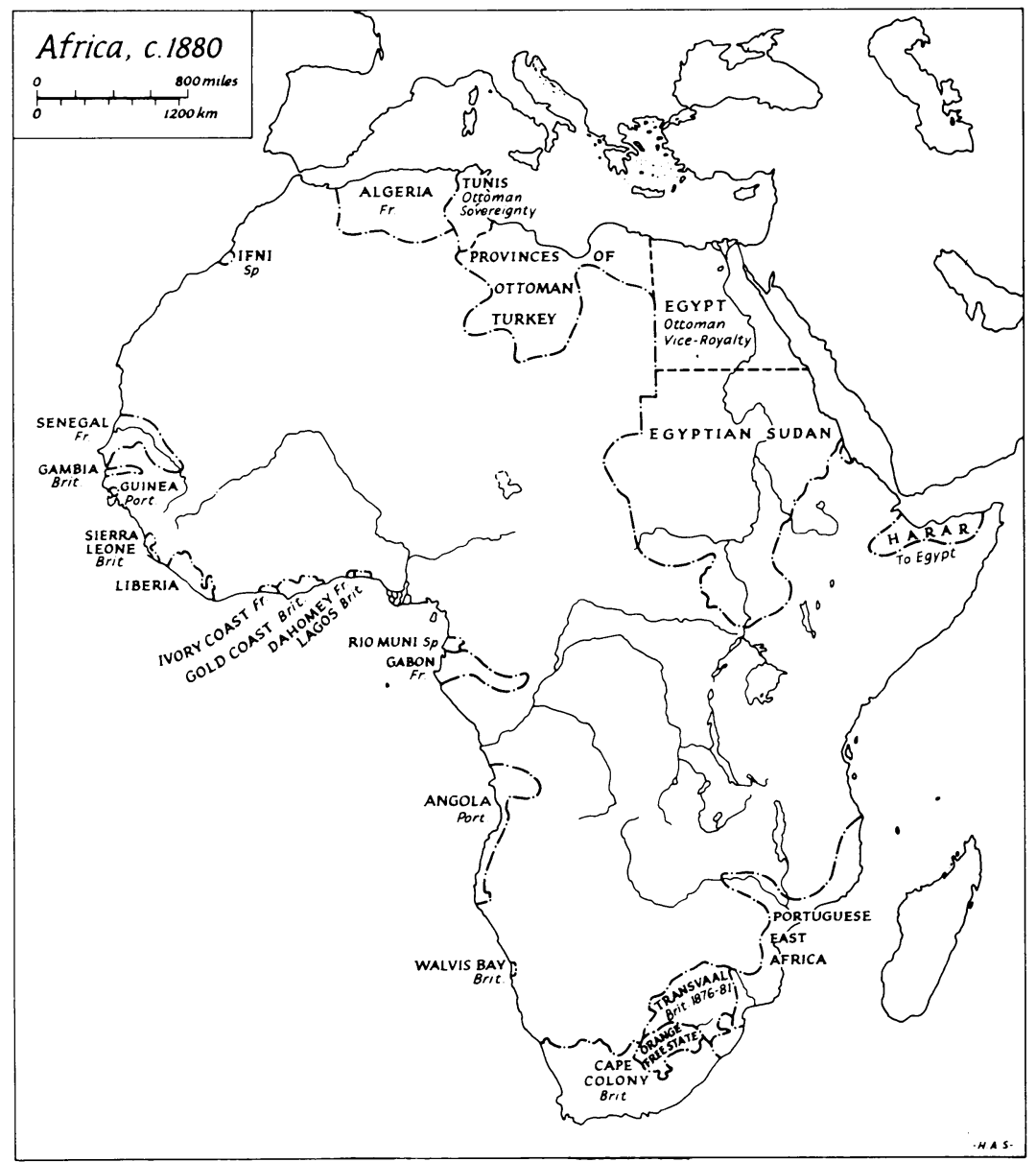

Map 2 


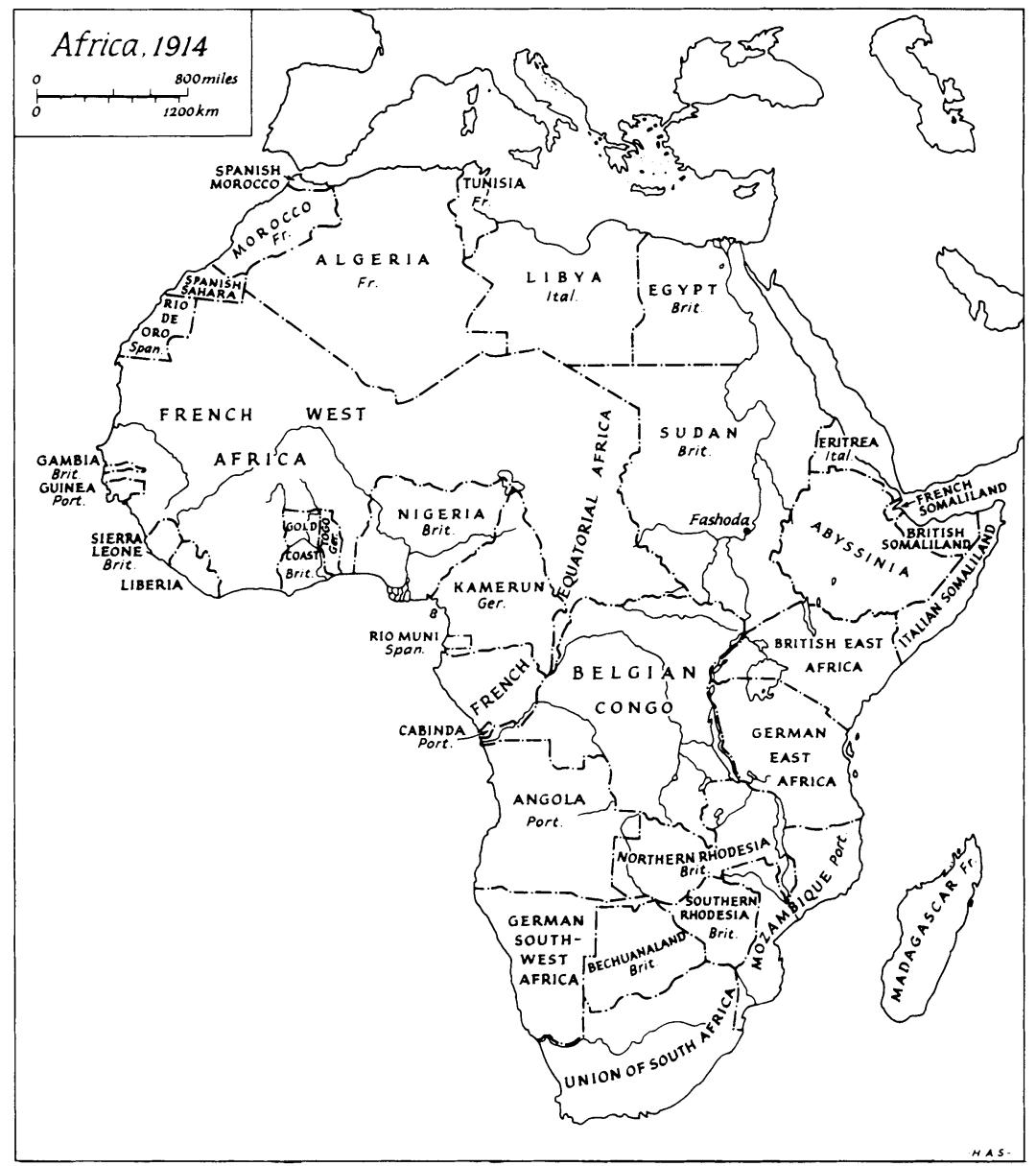

Map 3 


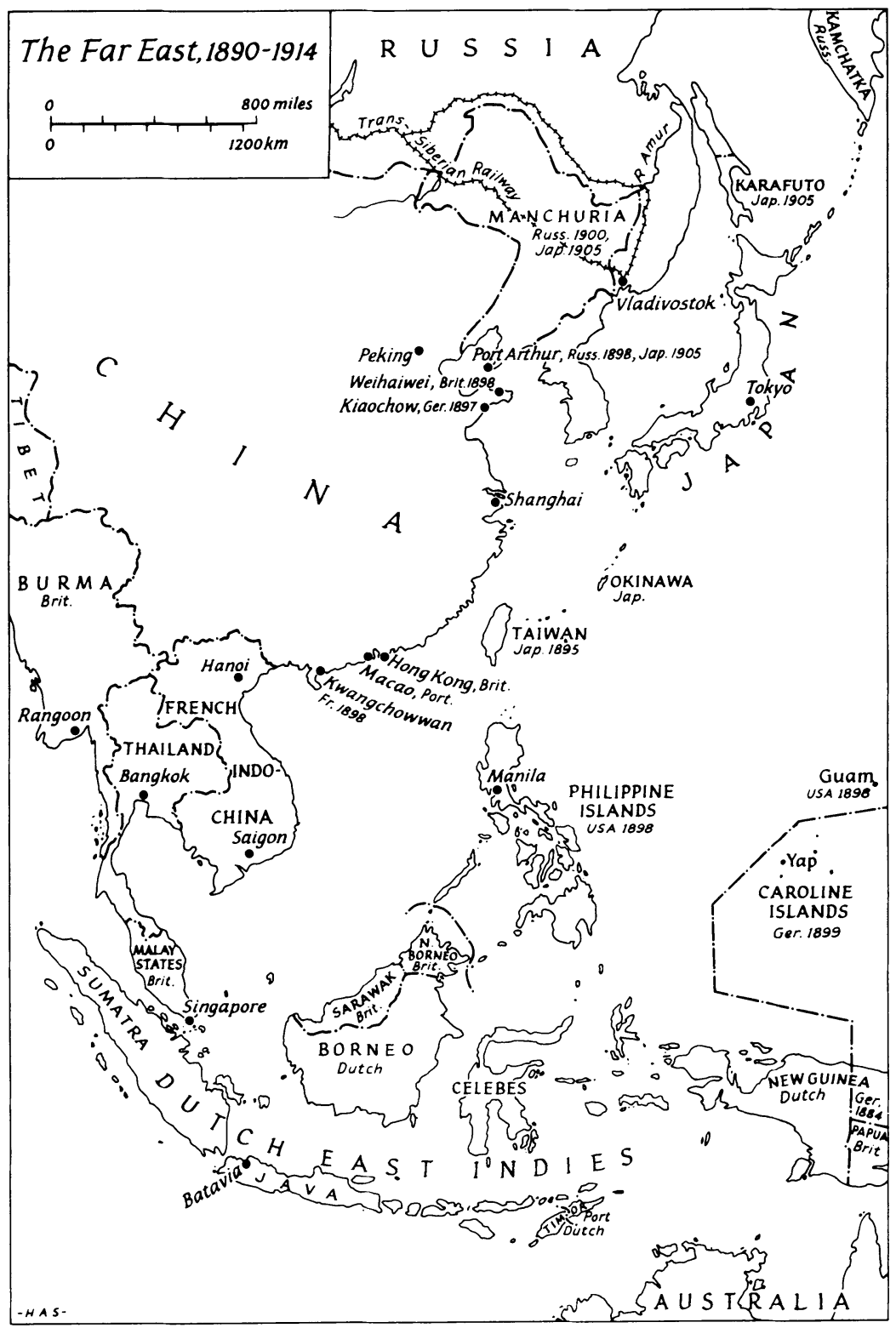

\section{Map 4}




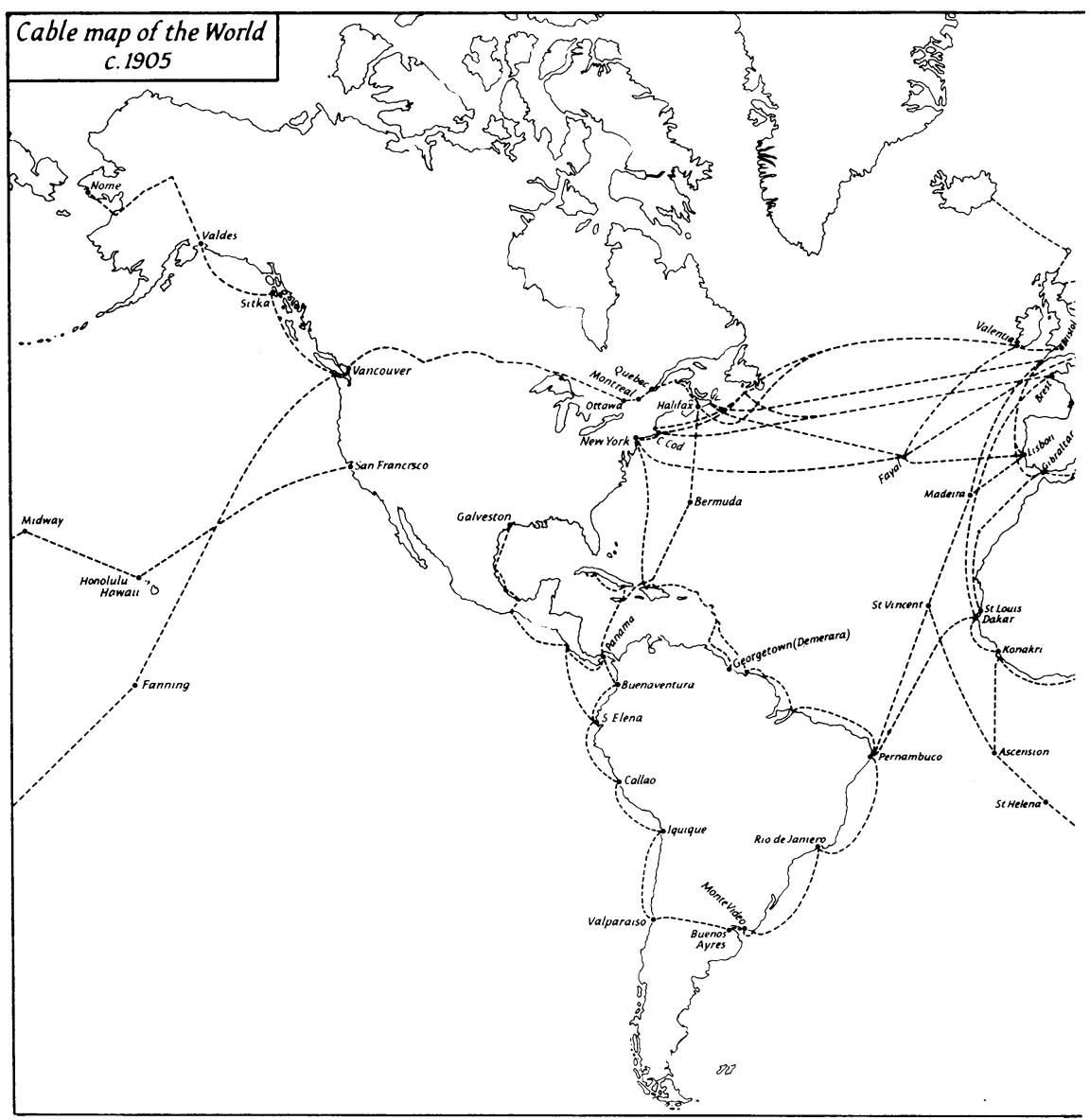

Map 5

Note for Map 5

A telegraphic map of 1855 published by the Electric Telegraph lines outside Europe, except for a temporary submarine cable across existed to Constantinople, though one was under construction. No intercontinental telegraph lines had yet been completed. By 1905 , as can be seen from this simplified map, a dramatic improvement had 


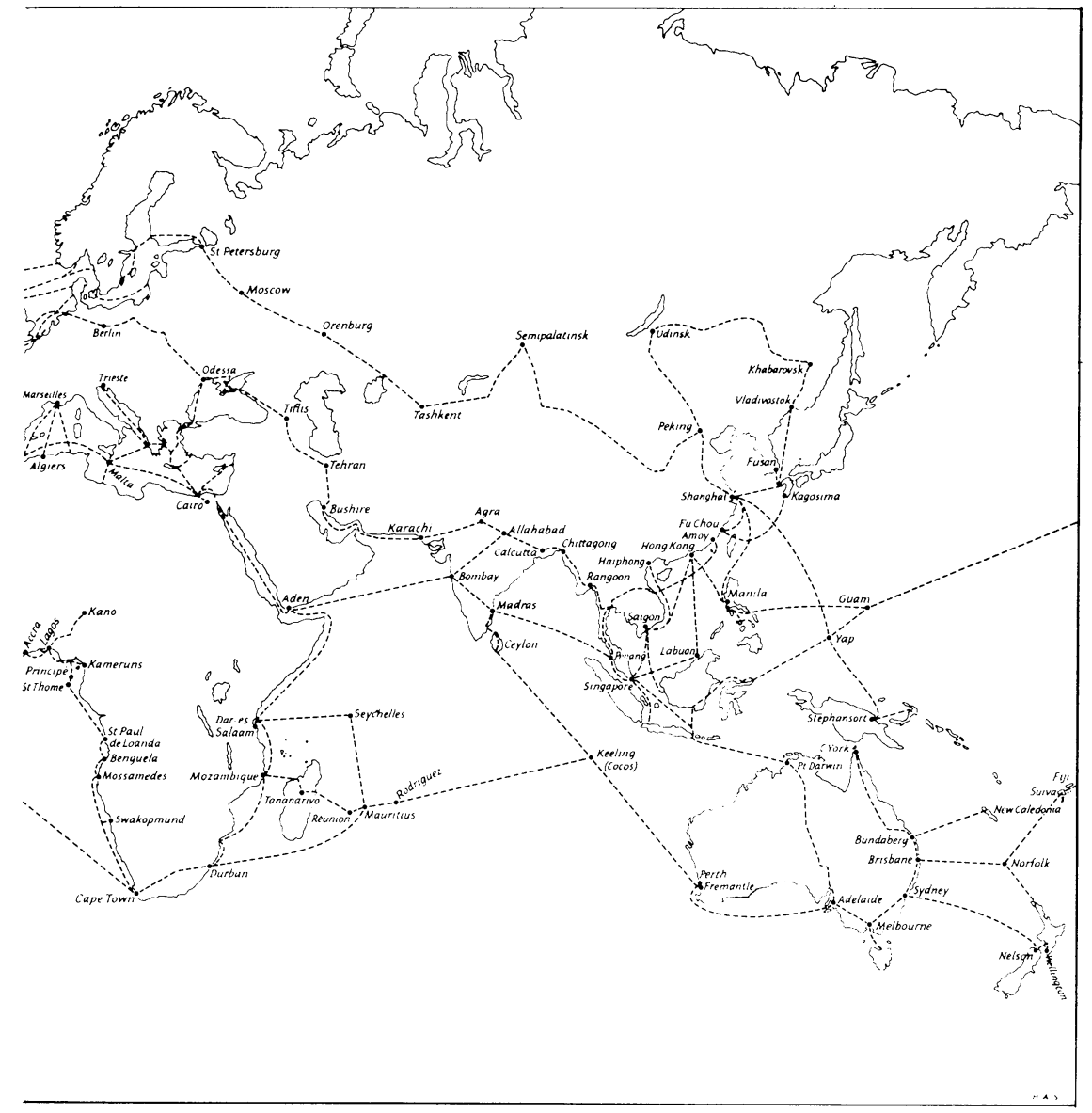

Company and the International Telegraph Company showed no the Black Sea from Varna to Balaclava in the Crimea. No line yet Except for Constantinople, all the European capitals were connected. however, all developed areas were equipped with domestic lines, and, taken place in intercontinental communications. 